\title{
Design and Performance Evaluation of a 1000-year Evapotranspiration-Capillary Surface Barrier
}

\author{
Z. Fred Zhang*a ${ }^{*}$ Christopher E. Strickland ${ }^{\mathrm{a}}$, Steven O. Link ${ }^{\mathrm{b}}$ \\ ${ }^{a}$ Hydrology Group, Earth Systems Science Division, Pacific Northwest National Laboratory, \\ Richland WA, USA 99352 \\ ${ }^{\mathrm{b}}$ Energy and Environmental Science Program, Department of Natural Resources, Confederated \\ Tribes of the Umatilla Indian Reservation, 46411 Timine Way, Pendleton, OR, USA 97801 \\ *Corresponding author \\ Email: fred.zhang@pnnl.gov \\ For submittal to the Journal of Environmental Management
}




\begin{abstract}
Surface barrier technology is used to isolate radioactive waste and to reduce or eliminate recharge water to the waste zone for 1000 years or longer. However, the design and evaluation of such a barrier is challenging because of the extremely long design life. After establishing a set of design and performance objectives, a package of design solutions was developed for 1000-year surface barriers over nuclear waste sites. The Prototype Hanford Barrier (PHB) was then constructed in 1994 in the field over an existing waste site as a demonstration. The barrier was tested to evaluate surface-barrier design and performance at the field scale under conditions of enhanced and natural precipitation and of no vegetation. The monitoring data demonstrate that the barrier satisfied nearly all objectives in the past two decades. The PHB far exceeded the Resource Conservation and Recovery Act criteria, functioned in Hanford's semiarid climate, limited drainage to well below the $0.5 \mathrm{~mm} \mathrm{yr}^{-1}$ performance criterion, limited runoff, and minimized erosion and bio-intrusion. Given the two-decade record of successful performance and consideration of the processes and mechanisms that could affect barrier stability and hydrology in the future, the results suggest the PHB is very likely to perform for its 1000-year design life. This conclusion is based on two assumptions: (1) the exposed subgrade receives protection against erosion and (2) institutional controls prevent inadvertent human activity at the barrier. The PHB design can serve as the basis for site-specific barriers over waste sites containing underground nuclear waste, uranium mine tailings, and hazardous mine waste.
\end{abstract}

Keywords: Surface Cover; Nuclear Waste; Infiltration Control; Waste Isolation 


\section{Introduction}

Surface barrier (aka surface cover) technology has been used for waste containment, e.g., at landfills, waste mine lands or tailings, and waste sites. Depending on the type of waste, the expected performance life varies drastically, from decades to millennia. Surface barriers for landfills generally have a relatively short ( $\sim 30$ years) design life and allow relatively large drainage (D) (hydraulic conductivity of about $10^{-9} \mathrm{~m} \mathrm{~s}^{-1}$ or $31.6 \mathrm{~mm} \mathrm{yr}^{-1}$ ) (EPA, 1989, 1991, 1992). Such barriers have been studies intensively and well documented (e.g., DOE-EM, 2000; Benson et al., 2001; Nyhan, 2005; Albright et al., 2010; Apiwantragoon et al., 2015).

Landfill barriers can be roughly categorized into conventional barriers and alternative evapotranspiration (ET) barriers. Conventional surface barriers rely on layers of material that resist downward water movement. These resistive layers are typically made of compacted clay, geomembranes, geosynthetic clay liners, or a combination of these materials. Conventional barriers are prone to problems such as increasing permeability with time (Benson et al., 2007; Henken-Mellies and Schweizer, 2011), preferential flow path development within the barrier (Albright et al., 2004), and cracking because of desiccation (Albrecht and Benson, 2001).

ET barriers are water storage and release barriers in which precipitation is stored till it can be released back to the atmosphere via ET. ET surface barriers are an alternative to conventional surface barrier, taking advantage of sustainable natural ecological systems and processes. ET barriers are expected to maintain performance longer than conventional barriers because they are not affected by the same issues as conventional barriers (e.g., increasing permeability with time, cracking because of desiccation)(Benson et al., 2007). Natural processes such as ecological succession and soil development enhance rather than degrade performance of ET barriers (Hauser, 2009). The ability of an ET barrier to store water for later release can be improved by 
including a capillary break (CB) beneath the storage layer (Albright et al., 2010), and such a barrier is referred to as an evapotranspiration-capillary (ETC) barrier hereafter.

The U.S. Environment Protection Agency initiated the Alternative Cover Assessment Project in 1998, and 10 conventional covers and 14 alternative covers at 11 sites across the U.S. were evaluated (Albright et al., 2004). The average percolation rate for alternative covers was $<2.2$ mm $\mathrm{yr}^{-1}$ in arid, semiarid, and subhumid climates. Scanlon et al. (2005) evaluated the ET covers at sites in Texas and New Mexico representative of arid and semiarid regions in the southwestern U.S. Using water balance monitoring during 4- and 5-year periods and computer simulations, they concluded that a 1-m-thick ETC barrier should be adequate to minimize drainage to $\leq 1 \mathrm{~mm}$ $\mathrm{yr}^{-1}$ in these regions. Studies of natural analogues suggest that such ET barriers are likely to perform for at least 1000 years (IAEA, 1989).

The surface barrier for uranium mill tailings (UMT) is designed for a 1000-year disposal life, where reasonably achievable and minimally for 200 years (EPA, 1996). Early UMT barrier designs focused on radon attenuation and longevity of the structure. In 1989, the Uranium Mill Tailings Remediation Program adopted a standard for low-permeability caps that required a saturated hydraulic conductivity of $<10^{-9} \mathrm{~m} \mathrm{~s}^{-1}\left(31.6 \mathrm{~mm} \mathrm{yr}^{-1}\right)$. Such UMT barriers were constructed at several sites, including Monticello, Utah (DOE-GJ, 1999; Waugh et al., 2008; DOE-LM, 2011b); Lakeview, Oregon (Bowerman and Redente, 1998; Waugh et al., 2007); and Blue Water, New Mexico (DOE-LM, 2011a). A few UMT projects in the U.S. are summarized in DOE (1996) and several international activities are provided in IAEA (2004). It appears that almost none of the conventional types of UMT barriers performed as designed, and hence some have been transformed into ET barriers (Benson et al., 2011). 
The surface barrier for underground nuclear waste is expected to perform for at least 1000 years (DOE-RL, 1999, 2016). There is no government code to guide the design of this type of barrier. The key difference between a landfill barrier and a 1000-year barrier is that their design life differs by about two orders of magnitude. This difference requires that several new factors (e.g., material degradation, erosion, intrusion, and infiltration) be addressed in the barrier design.

In spite of the similarity between UMT and underground nuclear waste barriers, the drainage rate allowed for nuclear waste is two orders of magnitude lower than that for the UMT. Radon emission and oxygen ingress must be controlled at the UMT, but may not be a concern for nuclear waste sites. The design life for the surface barrier for a nuclear site is also 5 times longer. Hence, the objectives and the design of a surface barrier for underground nuclear waste are different from those for UMTs. Additional concerns must be addressed in barrier design when the barrier life is expected to be longer. These concerns include (but are not limited to) material degradation, soil erosion, intrusion (of plants, animals, or humans), settlement, slope stability, and extreme climate conditions. Consequently, the complexity of barrier design can differ substantially, and the relatively simple barrier designs for landfills or UMTs are generally insufficient for radioactive waste sites.

Because of the 1000-year-long design life of the surface barriers for nuclear waste sites, field tests of such barriers must sustain much longer than for landfill barriers. However, there are very few barrier tests that have lasted over a decade and included stress tests. To address the concerns for the 1000-year barriers, a multi-year barrier study from 1984 to 1993 was conducted to develop, test, and evaluate the effectiveness of various barrier designs at the Field Lysimeter Test Facility (FLTF) at the Hanford Site near Richland, Washington (Phillips et al., 1988). Based on the test results from the FLTF, eight design/performance objectives were established (Table 1). 
The Prototype Hanford Barrier (PHB) was designed to meet those objectives and was constructed between late 1993 and 1994 as a demonstration of a 1000-year barrier (Wing and Gee, 1994; Gee et al., 1997; DOE-RL, 1999, 2016). Following construction, selected variables were monitored to verify barrier performance relative to the objectives in Table 1. In addition, a portion of the PHB was stressed with enhanced precipitation and controlled fire.

The purpose of the PHB demonstration was to evaluate surface barrier constructability, construction costs, and ecological/hydrologic/structural performance at field scale (DOE-RL, 2016). Ward and Gee (1997) summarized the performance of the PHB's ETC barrier from 1994 to 1996. Zhang (2015) analyzed the field water retention of the silt loam layer at four depths and 12 water balance stations using in situ measurements of water content and pressure from 1995 to 2003. Zhang (2016a) presented the hydrology of the PHB's ETC barrier from 1994 to 2013, while Zhang (2016c) presented the drainage that occurred under two side slopes and evaluated how the drainage from side slopes influences the effectiveness of a long-term barrier.

The purpose of this paper is to identify the objectives, describe the design solutions, and evaluate the performance of the PHB based on nearly two decades of monitoring data. Section 2 presents the objectives and design solutions, and describes the monitoring and stress tests conducted at the PHB. Section 3 delineates the PHB performance during the two-decade demonstration period and discusses the expected future performance, as appropriate, against the objectives. Finally, Section 4 summarizes the findings and implications for the design of future 1000-year barriers. 


\section{Objectives, design solutions, and stress tests}

This section presents the surface barrier objectives, design solutions, final barrier design, stress tests, and performance monitoring relevant to the design/performance objectives listed in Table 1.

\subsection{Issues and design solutions related to the barrier objectives}

\section{Objective \# 1: Meet or exceed RCRA criteria}

The purpose of this objective is to meet regulatory requirements that the barrier be at least as good as a Resource Conservation and Recovery Act (RCRA) cover, which has a design life of 30 years, a thickness is no less than $0.91 \mathrm{~m}$, and a hydraulic conductivity no more than $10^{-9} \mathrm{~m} \mathrm{~s}^{-1}$ (31.6 $\left.\mathrm{mm} \mathrm{yr}^{-1}\right)$. The design solution is to use an ETC barrier (the PHB) that is designed with a 1000-year design life, a thickness of about $4.5 \mathrm{~m}$, and a maximum drainage rate of $1.6 \times 10^{-11} \mathrm{~m} \mathrm{~s}^{-1}$ $\left(0.5 \mathrm{~mm} \mathrm{yr}^{-1}\right)$. Furthermore, the PHB includes a nearly impermeable layer at the bottom consisting of an asphalt concrete (AC) layer with a polymer-modified fluid applied asphalt (FAA) coating.

\section{Objective \#2: Function in a semiarid to subhumid climate}

The purpose of this objective is to ensure the surface barrier design functions in a semiarid climate, which is climate condition at the U.S. Department of Energy Hanford Site in southeastern Washington State. The design solution is to use an ETC barrier that functions in a semiarid climate. The Hanford Site, approximately 1517 square kilometers (586 square miles) in size, is located in southeastern Washington State, USA, and has a semiarid climate with typical dry, hot summers and cool, wet winters (Hoitink et al., 2005). The potential evapotranspiration 
(PET) at the Hanford Site is about 5 to 10 times the annual precipitation (P) (Wallace, 1977; Gee et al., 1989), making the climate at Hanford suitable for ETC barriers.

\section{Objective \#3: Limit drainage through the silt to less than $0.5 \mathrm{~mm} \mathrm{yr}^{-1}$}

The purpose of this objective is to minimize the amount of water that drains downward toward and through the subsurface zone containing contaminants. The design solution is to use a combination of a sufficiently thick store-and-release soil layer underlain by a capillary break that enhances the storage. The drainage rate of $0.5 \mathrm{~mm} \mathrm{yr}^{-1}$ is about two orders of magnitude less than that for a surface cover over landfills or UMTs. At this drainage rate, it would take approximately 10,000 years for drainage water to reach the underlying groundwater about $60 \mathrm{~m}$ below ground surface. It requires the surface barrier to have a very efficient store-and-release system to nearly eliminate drainage. To achieve this objective, the configuration of the ETC barrier, potential water ponding on barrier surface, and the handling of potential drainage were addressed as described below.

The ETC barrier. Warden silt loam from the nearby McGee Ranch was used to construct the storage layer from which ET processes recycle stored water back to the atmosphere. Coarser materials (sand overlying gravel) placed directly below the silt loam layer created a CB that inhibited the downward drainage of water from the silt loam into the coarser materials (Table 2). A 2-m-thick silt loam layer can store about $518 \mathrm{~mm}$ precipitation (Zhang, 2016a) without generating notable drainage. This storage is equivalent to approximately three times (3X) average annual precipitation (about $170 \mathrm{~mm}$ ) at Hanford. Hence, the silt loam layer has sufficient capacity to store all the precipitation of an extremely (once in 1000 years) wet year. For an ET barrier to be functional, the vegetation must be sustainable naturally. Vegetation at the Hanford 
Site consists of shrub-steppe plant communities composed of annual grasses and perennial grasses and shrubs (Rickard and Vaughan, 1988), a mixture of shallow and deep-rooted plants, which generally uses soil water very efficiently from roughly April to October (termed the summer season). The PHB surface and the surrounding disturbed areas were planted in the fall of 1994. Perennial shrubs were established by collecting seeds from local populations growing on the silt loam soil, growing seedlings, and planting them on the surface of the barrier. The silt loam used to construct the ETC barrier provides a medium for the growth of vegetation for transpiration. The vegetation is expected to sustain under the natural condition without additional management.

No ponding water on barrier surface. In the case of excess precipitation during a rainstorm or reduced hydraulic conductivity, e.g., because of ice formation, the barrier surface should not allow water to pond on the surface. Such ponding could lead focused infiltration that overwhelms the storage capacity of the barrier and leads to excessive drainage. This was achieved with a gently sloped barrier surface (2\%) that promotes lateral flow to limit the duration of ponding that might occur.

Drainage diversion. At the PHB, the FAA-coated AC has a permeability as low as $10^{-13} \mathrm{~m} \mathrm{~s}^{-1}$ $\left(0.003 \mathrm{~mm} \mathrm{yr}^{-1}\right)$, which is over two orders of magnitude lower than the design criterion of drainage of $0.5 \mathrm{~mm} \mathrm{yr}^{-1}$ for drainage. If some water manages to drain beneath the ETC barrier, e.g., because of preferential flow at some local area, the drainage layer above the nearly impermeable AC (Table 2) will promote lateral flow off the waste area. 


\section{Objective \#4: Limit runoff}

The purpose of this objective is to minimize the amount of runoff, which can lead to focused soil erosion of the barrier and localized ponding that results in excess infiltration. The design solution is to have a barrier that has a high infiltrability to handle the highest expected precipitation rates, and a gentle (but not zero slope) to promote runoff if and when surface ponding occurs.

To reduce water-induced soil erosion, the silt loam used to construct the barrier needs to have sufficiently high permeability so that runoff rarely occurs. At the PHB, the saturated hydraulic

conductivity $\left(\mathrm{K}_{\mathrm{s}}\right)$ of the silt loam was measured to be about $10^{-5} \mathrm{~m} \mathrm{~s}^{-1}\left(36 \mathrm{~mm} \mathrm{hr}^{-1}\right)$. Runoff is not expected under most precipitation conditions, except rare cases such as a reduced $\mathrm{K}_{\mathrm{s}}$ because of ice formation.

\section{Objective \#5: Minimize erosion}

The purpose of this objective is to have a barrier that minimizes wind- and water-induced soil erosion. Loss of soil reduces the water storage capacity of the ETC barrier, which could lead to increased drainage. Loss of soil reduces the volume of plant rooting material, which could reduce the plant community that removes water, thus potentially leading to increased drainage. Loss of soil reduces the depth through which animals would need to burrow to reach sublayers, thus potentially increasing the potential for animal intrusion of the underlying material.

The design solution is have a barrier surface that resists the wind and water forces without compromising the essential water storage and vegetation growth. The PHB includes two design features to minimize erosion: establishment of vegetation and addition of pea gravel to the top portion of the silt loam. Both of these design features control wind- and water-induced soil 
erosion. Vegetation was planted after barrier construction and obstructs both air and water flow above the ground surface and reduces splash erosion by intercepting raindrops. The top $1 \mathrm{~m}$ of soil was amended by adding about $15 \mathrm{wt} \%$ (dry weight) pea gravel. The decision to use $15 \mathrm{wt} \%$ pea gravel was based in part on the results of wind tunnel tests (Ligotke and Klopfer, 1990; Ligotke, 1993), and was also a compromise between water storage in the surface layer for plant growth and erosion mitigation. If some soil is lost from the barrier surface, the pea gravel will be left behind and form a rock armor to protect the barrier surface against further wind- or waterinduced soil erosion. After a wildfire burns off the vegetation, the rock armor will continue to function and it is expected that the barrier surface will be revegetated naturally after the fire.

\section{Objective \#6: Minimize biotic intrusion}

The purpose of this objective is to have a barrier that minimizes the ability of plants, animals and humans to intrude into the sublayers of the barrier and into the waste zone beneath the barrier. The design solutions are two-fold. One is based on the principle that the water-storage layer should be thick enough to provide sufficient depth to accommodate all natural plant growth and animal activity, taking into account the possible loss of some soil to erosion during the 1,000 design life. The other is based on the mechanical impedance to any intrusion.

The ETC barrier is guarded against plant, animal, and human intrusion from the sides by a gravel side slope in the west and a riprap side slope in the east (Figure 1). The west side slope is a 10:1 (horizontal:vertical) erosion-resistant pit-run gravel (aka clean-fill dike) side slope. It contains a small amount of fine (e.g., sand and silt) particles, and the gentle angle of the slope itself provides stability. The east side slope is made of basalt riprap with a size of about 0.2 to 0.3 m. A 1.5-m-thick riprap layer guards the barrier surface against intrusion. The riprap layer has a 
high mechanical strength and is to resistant animal burrowing and human digging and deters the growth of plant roots. Plant roots are not expected to penetrate through the riprap intrusionprevention layer. If some roots do penetrate the surface as the vegetation community changes, the AC layer will prevent the roots from penetrating into the waste zone.

\section{Objective \# 7: Have a design life of 1000 years}

The purpose of this objective is that the barrier must survive for at least 1000 years so that the radioactivity of the waste will have decayed to a sufficiently low level. It is expected that the surface will continue performing after the 1000-year design life. The design solution is to construct a barrier with very high stability and very low erosion risk. Soil erosion control has been addressed in Objective \#5. Barrier structural stability for 1000 years requires that issues such as material degradation, barrier subsidence, and slope stability over 1000 years be addressed in the design, and the approaches are described below.

Material degradation. Degradation of materials used to construct the barrier may reduce barrier structural stability and hence compromise barrier functionality. Synthetic materials used for some conventional barriers are not expected to last for the life of the barrier. Natural materials such as fine soil, sand, gravel, cobble, and basalt are in a near equilibrium condition and are not expected to experience considerable degradation during the 1000-year span of barrier life, and hence they were designated as construction materials for the PHB. The asphalt may suffer from aging, but this process is expected to be very slow under buried conditions without solar radiation and with reduced oxygen. The only synthetic material used was the geotextile at the bottom of the silt loam layer to prevent the fine particles of silt loam from entering the 
underlying sand during construction. Once barrier construction was completed, the geotextile was considered unnecessary and its degradation was not expected to affect barrier functionality.

Subsidence. The waste must be tightly packed and should not have large voids. The waste at the site consists of contaminated soil and a 30.5-cm-diameter corrugated steel pipe left in place within the waste zone. The soil subgrade was compacted to prevent the barrier foundation from settling, which could lead to cracking or other types of damage. A drainage layer with a $2 \%$ slope is included above the FAA-coated AC layer (Figure 1) to prevent the formation of standing water within the barrier so that the barrier and the side slopes will maintain their shear strength and structural stability.

Slope stability. The stability of the gentle (10:1) gravel side slope is not a concern. The angularity of the riprap of the 2:1 riprap side slope provides interlocking surfaces between adjacent rocks, allowing a relatively steep yet stable side slope.

\section{Objective \#8: Be maintenance free}

The purpose of this objective is to have a barrier that requires no maintenance so that longterm life cycle costs can be minimized and the barrier will be like a self-sustaining natural system. The design solution is to use natural materials in a layered configuration that is similar to the surrounding natural system that normal ecological and pedological processes will enhance rather than degrade barrier performance. As the barrier is expected to function in near equilibrium with the environment, no maintenance is expected. 


\subsection{PHB design, stress tests, and performance monitoring}

With all the issues considered, the PHB was designed as a system consisting of four main components (Figure 1): (1) a silt loam ETC barrier in the middle; (2) a 10:1 gentle pit-run gravel side slope in the west; (3) a 2:1 steep basalt riprap side slope in the east; and (4) an FAA-coated AC layer and a compacted soil layer at the bottom. The PHB covers an area of 2.5 ha (6.2 acres) in the 200 East Area of the Hanford Site and was deployed over the 216-B-57 Crib in the 200BP-1 Operable Unit. The description and design of the PHB have been reported in other sources (e.g., KEH, 1993; DOE-RL, 1994; Wing and Gee, 1994; Gee et al., 1997; Ward and Gee, 1997; DOE-RL, 1999, 2016; Zhang, 2016a).

The performance of the surface barrier was tested from 1994 to 2013 under both the natural and stressed conditions. The south section of the barrier was exposed to natural conditions all the time. Two stress tests were carried out at the north section of the PHB: (1) an enhanced precipitation (three times the average precipitation) test from water-year 1995 (WY95) to WY97 and (2) a controlled fire test in 2008. A water year is defined as the 12-month period from November to October. In late March of each year from 1995 to 1997, a 1000-year return 24-hour rainstorm was simulated on the north section. In September 2008, the vegetation in the north section was burned to test the impact of a natural fire on the barrier performance. The monitoring items and methods used to verify barrier performance are given in Table 1. A detailed description of the monitoring can be found in Zhang (2016b). 


\section{Results and discussion}

This section summarizes the performance of the PHB during the past two-decade monitoring period and discusses the expected future performance against the design and performance objectives, as applicable.

\subsection{Objective \#1: Meet or exceed RCRA criteria}

The RCRA thickness criterion of $0.91 \mathrm{~m}$ was realized when the PHB was constructed. The life span of the PHB is discussed in the section for Objective \#7. The RCRA permeability criterion does not apply to an ET barrier such as the PHB.

\subsection{Objective \#2: Function in a semiarid to subhumid climate}

\section{$\underline{\text { Site climate }}$}

During the barrier test period from 1994 to 2013, the average annual precipitation was $185.1 \mathrm{~mm} \mathrm{yr}^{-1}, 8.1 \%$ higher than the long-term average of $171.3 \mathrm{~mm}$. Here the precipitation effectiveness (PE) index of Thornthwaite (1931) was used to determine the climate type. A PE of $<16$ indicates an arid climate, a PE between 16 and 32 indicates a semiarid climate, and a PE between 33 and 127 indicates a subhumid climate. The PE at Hanford from 1945 to 2015 varied between 3.8 and 19.9, indicating that the climate at the site is between arid and semiarid. Under the 3-year enhanced precipitation condition, the PE was about 31, which falls near the boundary between semiarid and subhumid climate. It is noted that the climate category may be slightly different if a different climate index is used. However, they all generally indicate an arid to semiarid climate. 
The long-term (1945-2015) PET ranged between 2.3 and 9.5 with an average of 4.7 based on the Thornthwaite and Mather (1955) method and between 3.0 and 12.7 with an average of 6.1 based on the Hamon (1963) method. For an ET surface barrier to function effectively, the annual PET/P must be > 1. Hence, the PET/P at the Hanford Site is high enough for the use of an ET barrier. However, the monthly PET/P ratios were $<1$ from November to February based on the Thornthwaite and Mather (1955) method. This means excessive precipitation infiltrates into and is stored in the barrier soil during this period, and the storage layer must be thick enough for the precipitation during this period.

An extensive body of research has indicated that global average temperature and precipitation are expected to have an increasing trend (e.g., Christensen et al., 2007), although this will vary spatially. In the next century, the projected average precipitation could increase by as much as 30\% (Christensen et al., 2007). The future climate for the next millennium is largely unknown, but it may be inferred from the past. Petersen (1994) extracted the pollen record from the lake bottom sediments of Carp Lake, located near Goldendale, Washington, about $160 \mathrm{~km}$ southwest of the Hanford Site. This pollen record, dating back 75,000 years or more, indicates the types of vegetation that once grew near the lake and thus indicates the climate conditions necessary to support the growth of those types of vegetation. Based on the Carp Lake pollen record, Petersen (1994) stated that the mean annual precipitation 75,000 years ago ranged from $25 \%$ to $50 \%$ below to $28 \%$ above modern levels. This suggests that the precipitation could increase as much as $30-50 \%$. This precipitation increase is not expected to change the climate type at the Hanford Site. Assuming that the mean annual precipitation will increase by $30 \%$ in the future and the temporal variation will remain nearly the same as current, then the $P$ at the $99.9^{\text {th }}$ percentile would be $455 \mathrm{~mm}$ (Zhang, 2016a), smaller than the average $P$ of $496 \mathrm{~mm}$ during 
the 3-year enhanced precipitation test. If the $P$ will increase by $50 \%$, the $P$ at the $99.9^{\text {th }}$ percentile would be $525 \mathrm{~mm}$, which is equivalent to the storage capacity of the 2-m-thick silt loam layer.

There is a growing concern that the greenhouse effect will lead to global warming. Warmer climate is expected to cause higher PET, which will increase actual ET and thus reduce the likelihood for drainage. Hence, the test results at the PHB with the current design will likely represent the hydrological condition in the next millennium, even with climate change.

\section{$\underline{\text { Vegetation }}$}

For the surface barrier to be effective, the vegetation must grow well and sustain in the barrier under the local climate. The revegetation on the PHB in 1994 was successful but resulted in a near monoculture of Artemisia tridentate (big sagebrush) initially. Over time, the plants at the PHB formed a community containing shrubs, grasses, forbs, and soil cryptogam, with plant litter on the ground. The number of species on the unburned section of the barrier increased after the initial construction disturbance, with the highest number of species (35) observed in 1997 , then dropped to low levels (11) in 2008, and increased to an intermediate level (34) in 2010. This result indicates that the vegetation at the PHB was robust.

Roots grew to the bottom of the assessment tube viewing position (about $1.75 \mathrm{~m}$ ) in the first year after planting in the irrigated section and by the second year in the ambient precipitation section (Gee et al., 1996). These roots are primarily those of A. tridentata. This indicates that the deep-rooted $A$. tridentata shrubs could access nearly the entire soil profile for barriers after construction and was able to transpire the stored water in the 2-m-thick silt loam layer.

In the arid climate of Hanford, wildfires are expected to occur many times during the 1000year life of a surface barrier. The recovery of vegetation after fire is critical to the function of a 
surface barrier. After the controlled fire in 2008, vegetation cover was significantly reduced. One year after the fire, the mean leaf area index on the burned section of the barrier $(0.254 \pm 0.02)$ was about $22 \%$ of that on the unburned section $(1.13 \pm 0.087)$. The number of species increased from 10 in 2008 (before the fire) to 24 in 2009 (1 year after the fire) and subsequently dropped to 15 in 2011. After the fire, Mespilus canescens (hoary tansyaster), a biennial forb, dominated and had a coverage of $27.9 \%$ in 2010 . The significant increase in cover of $M$. canescens after the fire was likely caused by wind-blown seed from some distance, as there were none in the seed bank after the fire. The unanticipated high cover of $M$. canescens after the fire suggests that this species may be able to resist Bromus tectorum (cheatgrass) invasions, and possibly may be a useful species for general fire restoration efforts. It was observed that $A$. tridentata emerged from the seed bank after the fire, which suggests that this shrub will return after a fire. This observation is in contrast to the general belief that $A$. tridentata does not recover after a fire (Tirmenstein, 1999). Given that the fire had little effect on the seed bank on the barrier, it is expected that fire poses little risk to the potential plant communities that can arise from the naturally occurring seed bank.

\subsection{Objective \#3: Limit drainage through the silt to less than $0.5 \mathrm{~mm} \mathrm{yr}^{-1}$}

\section{$\underline{\text { Hydrology at the ETC barrier }}$}

A detailed description of the hydrology in the ETC barrier of the PHB can be found in Zhang (2016a). The main findings are briefly summarized here. The store-and-release mechanism for the ETC surface barrier worked efficiently. The silt-loam layer was recharged in the winter season (from November to March) from top to bottom. Nearly all the stored water and precipitation in the summer season (from April to October) was released into the atmosphere via 
ET. The CB functioned normally. During the test of enhanced precipitation, infiltration water reached the $\mathrm{CB}$, but the wetness was lower than the entry value. The observed mean of the highest water storage values over six monitoring stations was $518 \mathrm{~mm}$. Water diversion due to the $2 \%$ slope of the barrier surface was observed in the irrigated north section.

Because of the effectiveness of the ETC barrier, drainage from the barrier was extremely small. The maximum drainage rate observed was $0.18 \mathrm{~mm} \mathrm{yr}^{-1}$ in WY97 in the northeast part of the barrier. The average drainage rate from WY95 to WY12 through the ETC barrier was 0.005

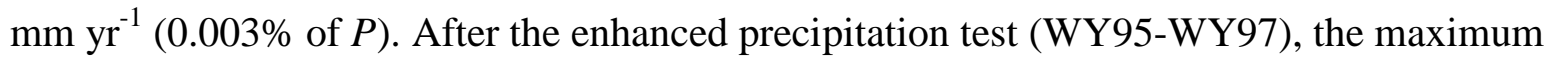
drainage rate measured was $5.8 \times 10^{-3} \mathrm{~mm} \mathrm{yr}^{-1}$ and occurred in the northwest part of the barrier in WY07; all other measurements were either zero or at the magnitude of $10^{-5}$ to $10^{-4} \mathrm{~mm} \mathrm{yr}^{-1}$.These drainage rates were much less than the design drainage criterion of $0.5 \mathrm{~mm} \mathrm{yr}^{-1}$.

\section{Effect of soil development on future barrier performance}

Soil development refers to the changes to soil properties over very a long period of time (hundreds to thousands of years or longer) and may affect the functionality of the ETC barrier and hence its performance. For an engineered system, soil changes can occur in response to the soil formation processes of illuviation-eluviation and pedoturbation (Schaetzl and Anderson, 2005). The illuviation-eluviation process differentiates a uniform soil mass into distinctive layers (horizons) through transformation and translocation of soil components (e.g., clay, Fe, Al, humus, carbonate, and silica). The pedoturbation process tends to inhibit soil horizonation by mixing layers formed previously. When acting simultaneously, layer formation still occurs, but it is in response to both processes.

Because of soil development processes, natural soils generally contain several horizons (or layers) that are used to classify soils. For example, the Warden silt loam soil series at Hanford 
(Hajek, 1966) typically has a surface layer that is underlain by a calcareous zone. When a barrier is built, no layering exists in the silt loam; however, given enough time, soil formation processes will slowly transform the material into something resembling a natural soil. This implies that the silt loam used for the barrier surface material will slowly evolve to be similar to a Warden silt loam soil, possibly over centuries or millennia. Based on data from Rockhold et al. (1988), the particle size distribution and hydraulic properties of Warden silt loam at the 20-cm depth are similar to those at the 60-cm depth. Waugh (2011) found that difference in soil structure of the Montecello surface barrier had little influence on the hydraulic conductivity of the water storage layer. These findings suggest that the developed soil layers do not have considerably different hydraulic properties. Thus, soil formation within the silt loam layer is not expected to affect the hydrologic performance of the barrier in the next 1000 years.

The pedoturbation processes that mix soil components, usually at relatively shallow depths, can be caused by burrowing animals, soil fauna (e.g., worms), plant root growth, and paired processes such as freezing-thawing, wetting-drying, and swelling-shrinking. The pedoturbation processes keep the soil in a dynamic condition so that channels for potential preferential flow, such as old animal burrows, root channels, and soil structures, are destroyed gradually after they are formed. Benson et al. (2007) observed that the hydraulic properties of cover soils converge to common values of natural soils over time. Sometimes pedoturbation creates large conduits that could be avenues for preferential flow when the barrier becomes saturated. The PHB is designed with a $2 \%$ slope of barrier surface to reduce the possibility of ponding water. This will reduce the chance of saturated flow and hence preferential flow through the large conduits. Hence, it is likely that the ETC barrier will function normally as the soil evolves slowly under the natural biological and climatic conditions. 


\subsection{Objective \#4: Limit runoff}

During the monitoring period, three events contributed a total runoff of $38.1 \mathrm{~mm}$, of which $36.3 \mathrm{~mm}(95 \%)$ was due to a snowmelt event in January 1997. The results indicate that snowmelt events on frozen ground pose a higher risk than the 1000 year return, 24-hour rainstorms for generating runoff. A snowmelt event on frozen ground happens approximately once in a decade. For example, the previous snowmelt-caused ponding occurred in March 1985 (Gee, 1987). According to Stone et al. (1983), the 1000 year return, 1-hour rainstorms have the intensity of 1.1 inches $\mathrm{hr}^{-1}\left(27.9 \mathrm{~mm} \mathrm{hr}^{-1}\right)$, which is comparable to the $\mathrm{K}_{\mathrm{s}}$ of the barrier soil. Considering that short-time infiltration rate is generally much higher than the $\mathrm{K}_{\mathrm{s}}$ of the soil (Hillel, 1980), the chance for runoff to occur under the 1000 year return, 1-hour rainstorms is still very low.

In the future, coppice dunes may be formed by accumulating eolian dust or sand around the base of shrubs. At McGee Ranch, the coppice dunes are circular-to-oblong with diameters of 1 to $3 \mathrm{~m}$ and heights between 0.2 and $0.7 \mathrm{~m}$ (Link et al., 1994; Waugh et al., 1994). The time needed to form coppice dunes is uncertain. The formation of coppice dunes could influence water flow processes and soil water balance of the ETC barrier, but it is not expected to reduce the storage capacity of the ETC barrier. The coppice dunes may enhance local runoff during rainstorms or snowmelt events, causing more infiltration in the area between the dunes. Because the vegetation can grow on and between the dunes, the basic store-and-release mechanism will still function. 


\subsection{Objective \#5: Minimize erosion}

\section{$\underline{\text { Vegetation and wind erosion }}$}

Vegetation's effectiveness at protecting the ground surface against wind erosion is dependent on the height (above ground surface) at which wind velocity is reduced to zero, termed surface roughness. Higher surface roughness means better protection against wind erosion. Surface roughness generally increases with the height and/or coverage of vegetation.

Based on the monthly average wind speed profile, estimates of barrier surface roughness were made for each month and are shown as points in Figure 2. From the planting of vegetation on the barrier in November 1994 until about April 1995, the surface roughness was near zero. After May 1995, when the vegetation was established, the surface roughness varied seasonally in each year, with higher values generally in the summer season. This is most likely due to increased leaves and/or flowers of sagebrush during the growing season and higher coverage of annuals and limited bi-annuals. Hence, the vegetation had a greater ability to reduce wind in the summer. This implies that, for a given year, the barrier was more resistant to wind erosion in the summer season than in the winter season. Across different years, the low values (roughly in early spring) of barrier surface roughness at stations 1 and 2 (Figure 2) increased from near zero in 1995 to about $0.05 \mathrm{~m}$ in 1997 . This increase suggests that the barrier was likely well protected from wind erosion year round starting in 1997. Additionally, the stronger wind in late spring and summer coincided with higher surface roughness. As a result, the strong wind in the spring/summer was offset by the higher roughness of the barrier surface. These results indicate that the vegetation increased the height of zero wind velocity above the barrier surface and suggest reduced possibility of wind erosion. 
It is noted that dust traps were used at the PHB, but were removed in December 1995 because of the lack of dust, which was attributed to vegetation growth and the relatively high soil water content at the barrier surface. Future wind erosion may be increased by the occurrence of tornados. Myers and Duranceau (1994) evaluated the historical evidence for tornados near the Hanford Site. Wind data collected at the Hanford Site and surrounding locations were used to develop probabilistic straight-wind and tornado hazard assessments. Straight-wind velocities that equal or exceed tornado velocities have return periods of about 100,000 years. Hence, tornado winds are expected to be extremely rare on the Hanford Site.

\section{$\underline{\text { Water erosion }}$}

During the simulated 1000-year-return, 24-hour rainstorm (69.4 mm of water over an 8-hour period) on the newly vegetated surface in March 1995, erosion occurred on the surface of the barrier (Gee et al., 1995). Initial sediment concentrations collected during the test were approximately $7 \mathrm{~g} \mathrm{~L}^{-1}$. This amount fell to approximately $1 \mathrm{~g} \mathrm{~L}^{-1}$ at the end of the water application. The results showed a decreasing pattern of erosion, indicating less soil was eroded, possibly because more pea gravel was exposed. The estimated soil erosion was about $72 \mathrm{~kg} \mathrm{ha}^{-1}$ in total. No soil erosion was observed during the rest of the monitoring period, including during the simulated 1000-year-return rainstorms in 1996 and 1997, during the snowmelt event in the January 1997, and after the controlled fire in 2008. As discussed above, although snowmelt events on frozen ground pose a high risk for generating runoff, the events may not produce any erosion because the surface soil may be frozen and covered with snow. A Chinook wind is a warming wind from the ocean into the interior regions and can rapidly melt deep snow causing significant runoff. The primary reasons for the lack of runoff and erosion were the sufficiently high soil hydraulic conductivity and the increased coverage of vegetation on the ground surface. The 15 
wt $\%$ pea gravel in the top $1 \mathrm{~m}$ of the barrier protects the barrier surface from erosion because of its weight, and hence protects against the formation of runoff channels such as rills or gullies (Gilmore and Walters, 1993).

As an analog of the erosion control at the PHB for the future, a similar mixture of gravel appears to be the primary reason for longevity of natural bergmounds formed from ice-rafted glacial debris about 13,000 years ago (Fecht and Tallman, 1978; Chamness, 1993; Bjornstad, 2014).

\subsection{Objective \#6: Minimize biotic intrusion}

The biotic intrusion is primarily attributed to animal activities. Potential intrusion risks because of animal activities for barrier function include the formation of large holes, mounding, and damage to plants. From 1994 to 2013, the largest hole was $0.3 \mathrm{~m}$ in diameter and $0.6 \mathrm{~m}$ deep. There was one mound observed that was $0.09 \mathrm{~m}$ tall. The results indicate that burrowing animals likely do not affect barrier function.

Before the PHB demonstration, an Animal Intrusion Lysimeter Facility was constructed in 1988 to evaluate the impacts of burrowing animals on engineered surface barrier performance (Cadwell et al., 1989; Landeen, 1990, 1991, 1994). These studies indicate that most animal burrows do not extend below $1 \mathrm{~m}$, since the most favorable environmental conditions (e.g., food, water, shelter, and temperature) are found within the top $1 \mathrm{~m}$ below ground surface, with the exception of the Western harvester ant (Gano and States, 1982). Although the soil brought to the surface by burrowing animals can be more susceptible to erosion, the erosion can be mitigated by adding gravel admix to the upper portion of the soil. Precipitation water infiltrated to larger depth in the soil around an animal burrow, but most of the water was later removed by a variety of 
processes (e.g., drying via ventilation effects from open burrows and transpiration from plants). Abandoned badger burrows were often quickly backfilled with soil and organic debris.

Although the 1.5-m-thick riprap layer will deter the human digging activities, institutional controls are also expected in order to prevent inadvertent human activities at the barrier.

\subsection{Objective \#7: Have a design life of 1000 years}

In the following, barrier structural stability is evaluated based on the monitoring of subsidence, compaction, and side slope stability. The potential degradation of asphalt and natural disruptive events are discussed.

$\underline{\text { Subsidence, compaction, and side slope stability }}$

From 1994 to 2012, the average elevations with \pm 1 standard deviation $(\sigma)$ of the two settlement markers were $201.956 \pm 0.007 \mathrm{~m}$ and $201.685 \pm 0.012 \mathrm{~m}$, respectively, without clear trends over time. For both markers, the elevation variations were between -0.03 and $0.02 \mathrm{~m}$, indicating near-zero settlement. Considering that the small variations were probably measurement noise, the results suggest a very stable AC barrier, subgrade, and waste zone.

Plots for the first survey of barrier surface elevation in 1994 and last survey in 2012 are shown in Figure 3 . The plots reflect the $2 \%$ slope from the crown. The spatially averaged elevation change over time is shown in Figure 4. During the 18-year monitoring period, the shape of the barrier surface stayed relatively constant. From 1994 to 2012, the average elevation change with $1 \sigma$ was $0.003 \pm 0.018 \mathrm{~m}$, which is negligible. There is no noticeable difference between the north and the south sections. The north section was irrigated to $3 \mathrm{X}$ the long-term average precipitation from WY95 to WY97 and the vegetation on it was burned by the controlled 
fire in 2008, while the south section was exposed to natural conditions for the duration of the study. The above results indicate that both the base and barrier had an appropriate density, so neither compaction nor deposition happened during the reported monitoring period of 18 years.

Negligible movement of the riprap side slope was observed during the 18 -year monitoring period. Figure 5 shows the positions of the creep gauges (CGs) in the final survey in 2012 (2011 for CG12 and 2010 for CG10a) relative to their corresponding initial positions in 1994. Of the 15 CGs, 12 had positive changes up to $0.083 \mathrm{~m}$ to the outward east, 13 had positive changes up to $0.033 \mathrm{~m}$ to the north, and 13 had negative changes down to $-0.018 \mathrm{~m}$ (shown as the empty circles) in the vertical direction. On average, over the $15 \mathrm{CGs}$, the changes with $1 \sigma$ are $d x=$ $0.023 \pm 0.032 \mathrm{~m}, d y=0.020 \pm 0.012 \mathrm{~m}$, and $d z=-0.007 \pm 0.006 \mathrm{~m}$. The average changes are comparable to the standard deviation, indicating that any changes are beyond detection and the riprap side slope was very stable during the monitoring period.

The aerial images (Figure 6) taken in 1994, when the PHB construction was completed, and 21 years later, in 2015, show that, other than the vegetation that developed on the PHB and the surrounding area, there is no visual difference between the main components of the PHB, i.e., the ETC barrier and side slopes. Although Figure 6 shows no visible change in the PHB, it shows changes in the terrain of the subgrade at the east side to the PHB and the terrain of the north portion of the gravel side slope. The rectilinear slope of the exposed subgrade is less steep in 2015 and the sharp edge becomes rounded. Additionally, the rainstorm event in May 2004 led to runoff from nearby facilities that eroded a small section of the toe of the steep riprap side slope. The barrier design did not consider an event of this nature. The erosion did not affect the stability of the side slope and was repaired. The occurrence of the flood and the soil erosion at the toe of the steep riprap side slope indicates that the topology around the barrier, the resultant run- 
on/runoff, and the surrounding surface hydrology can play an important role in barrier integrity. Therefore, barrier design needs to consider protection of the toes of side slopes, particularly riprap side slope.

The current side slopes have constant gradients (10:1 in the west and 2:1 in the east), while natural analog indicates that a more stable slope usually has a convex shape in the upper portion and a concave shape near the toe (Schor and Gray, 2007). The low elevation areas around the barrier toe will have a high probability of being future runoff channels, and hence proper protection (e.g., with gravels and/or vegetation) is needed for soil erosion.

\section{$\underline{\text { Potential long-term degradation of asphalt }}$}

There is a concern about the aging of the asphalt used at the AC layer. As asphalt ages, its average molecular size increases because of oxidative reactions that combine smaller molecular weight materials into larger molecules. The increase in molecular size is one of the primary factors in age-hardening of asphaltic materials. Freeman et al. (1994) studied buried archaeological asphalt artifacts, ranging in age from 500 to 4000 years, analogous with the asphalt component of the PHB. The percentage of large molecular size materials was quantified. The fraction of large molecular size materials increased from about $0.4 \%$ for fresh asphalt to about $2.4 \%$ for 4000 -year-old asphalt artifacts. These results indicate that, under buried conditions (i.e., no solar light, reduced oxygen), the aging processing appears to be extremely slow.

Potential natural disruptive events in the future 
The nearest volcano is the extinct Goat Rock volcano in the Cascade Range $\left(46^{\circ} 29^{\prime} 19^{\prime \prime} \mathrm{N} 121^{\circ} 24^{\prime} 21^{\prime \prime} \mathrm{W}^{1}\right)$, approximately $110 \mathrm{~km}$ west of the Hanford Site. Tephra from the Cascade volcanos has been found in the sediments in and around the Hanford Site. During the 1980 volcanic eruption of Mount St. Helens $\left(46.20^{\circ} \mathrm{N} 122.18^{\circ} \mathrm{W}^{2}, 200 \mathrm{~km}\right.$ southwest of Hanford), about $1 \mathrm{~cm}$ of ash fell on the northern part of the Hanford Site (Myers and Duranceau, 1994). The volcanic hazard depends on the Cascade eruptive activity and the meteorological conditions that control the direction and distance of air transport. A small amount of volcanic ash is not expected to affect PHB life.

The Columbia River Plateau region is an area of low magnitude seismicity compared to the rest of the western U.S. The most significant earthquake relative to the Hanford Site is the 5.75 magnitude quake that occurred in 1936 near Milton-Freewater, Oregon, which is more than 90 $\mathrm{km}$ to the southeast. Hence, the probability of PHB damage by tornados, volcanos, and earthquakes appears to be very low.

\subsection{Objective \#8: Be maintenance free}

After the completion of the PHB construction and revegetation in 1994, there was no maintenance at the PHB, other than instrumentation, except the filling of an animal hole that was about $0.6 \mathrm{~m}$ deep with a $0.3 \mathrm{~m}$ diameter. No maintenance was required to keep the functionality of the barrier, indicating the barrier functions like natural system with a variety of ecological and pedological processes happening normally. There is no foreseeable maintenance necessary for the PHB in the future.

\footnotetext{
${ }^{1}$ https://en.wikipedia.org/wiki/Goat_Rocks.

${ }^{2}$ https://en.wikipedia.org/wiki/Mount_St._Helens.
} 
In May 2004, after severe thunderstorms, runoff water from the adjacent elevated BY-BX Tank Farm surface (southeast of the PHB) flowed down-gradient to the region between the Tank Farm and the PHB, eroding a channel about $1.1 \mathrm{~m}$ deep beyond the PHB boundary but near the base of the east side of barrier side slope. The channel extended into the sandy structural fill layer below the riprap side slope. A repair was made in the following year. The occurrence of the flood indicates that the topology around the barrier, the resultant run-on/runoff, as well as the surrounding surface hydrology can play an important role in the integrity of the barrier, and hence protecting the toe of the riprap side slope needs to be considered in the design.

\section{Summary}

The PHB functioned as designed during the entire period of monitoring, which stretched from the completion of construction in 1994 to the end of the monitoring period in 2013. Monitoring activities included hydrological stress tests that exceeded stresses expected over the next 1000 years. Most importantly, PHB performance demonstrated that the barrier satisfied nearly all key objectives, with an exception for minimal maintenance by filling an animal hole. The PHB far exceeded the RCRA criteria, functioned in Hanford's semiarid climate, limited drainage to well below the $0.5 \mathrm{~mm} \mathrm{yr}^{-1}$ performance criterion, limited runoff, and minimized biointrusion and erosion.

Given the two-decade record of successful performance and consideration of all the processes and mechanisms that could degrade the stability and hydrology in the future, the results suggest the PHB is very likely to perform for its 1000-year design life. This conclusion is based on two assumptions: (1) the exposed subgrade receives protection against erosion and (2) institutional controls prevent inadvertent human activity at the barrier. The PHB design can serve 
as the basis for site-specific barriers over waste sites such as the underground nuclear waste, UMTs, and hazardous mine waste.

The PHB design can be modified for the sites containing other types of wastes, e.g., uranium mill tailings, mine tailings or mine lands, and hazardous waste landfills. Depending on the hazardousness of the waste sites, the intrusion prevention layer could be thinned or removed. UMTs contain a low level of radioactive radium radon gas, which is carcinogenic. Mine tailings often generate acid mine drainage (AMD) when the sulfur-containing tailings are oxidized. A surface barrier like the PHB or a modified version can be used to isolate the UMTs or mine tailings. The AC layer or a modified version can serve as a layer to prevent the release of radon gas from the UMTs or reduce the ingress of water and $\mathrm{O}_{2}$ into the mine tailings and hence reduce AMD generation. The silt loam storage layer probably can also be thinned, depending the maximum allowed drainage rate from the barrier and the minimum thickness for the normal growth of vegetation.

However, a surface barrier cannot remove the water already in the vadose zone before barrier deployment. For the case when the waste resides in the relatively deep (e.g., tens of meter) vadose zone, it will take time (e.g., years or decades) for a surface barrier to start slowing down the migration of contaminants in the underlying vadose zone. If the waste resides very close to the groundwater, the contaminants in it could migrate to the groundwater before the surface barrier starts to take effect because of this time delay. Hence, a detailed analysis of flow and contaminant transport should be conducted to determine the suitability of such sites for surface barrier use. 


\section{Acknowledgement}

Funding for this research was provided by the U.S. Department of Energy Richland Operations Office under the Deep Vadose Zone Project. Pacific Northwest National Laboratory is operated for the U.S. Department of Energy by Battelle under Contract DE-AC05-76RL01830. The author, Dr. Z. F. Zhang, managed a portion of the test period and prepared this manuscript. Numerous other individuals contributed to the Hanford Barrier program during its existence. Their contributions range from design and engineering to field monitoring support and analysis. Key individuals include Dr. Glendon W. Gee of PNNL, the principal scientist for design and installation of the barrier, Dr. Andy L. Ward of PNNL, who managed the test and data collection for most of the test period, and Dr. Kevin D. Leary of the Department of Energy, who directed monitoring activities and is the inspiration behind the controlled burn and subsequent natural recovery monitoring. The data in this paper belong to the U.S. Department of Energy and the author has permission from the data owner to use this data.

\section{References}

Albrecht, B.A., Benson, C.H., 2001. Effect of Desiccation on Compacted Natural Clays. Journal of Geotechnical and Geoenvironmental Engineering 127, 67-75.

Albright, W.H., Benson, C.H., Gee, G.W., Roesler, A.C., Abichou, T., Apiwantragoon, P., Lyles, B.F., Rock, S.A., 2004. Field Water Balance of Landfill Final Covers. Journal of Environmental Quality 33, 2317-2332.

Albright, W.H., Benson, C.H., Waugh, W.J., 2010. Water Balance Covers for Waste Containment Principles and Practices. ASCE Press, Reston, Virginia. 
Apiwantragoon, P., Benson, C.H., Albright, W.H., 2015. Field Hydrology of Water Balance Covers for Waste Containment. Journal of Geotechnical and Geoenvironmental Engineering $141,04014101$.

Benson, C.H., Abichou, T., Albright, W.H., Gee, G.W., Roesler, A.C., 2001. Field Evaluation of Alternative Earthen Final Covers. International Journal of Phytoremediation 3, 105-127.

Benson, C.H., Sawangsuriya, A., Trzebiatowski, B., Albright, W., 2007. Post-Construction Changes in the Hydraulic Properties of Water Balance Cover Soils. Journal of Geotechnical and Geoenvironmental Engineering 133, 349-359.

Benson, C.H., Waugh, W.J., Albright, W.H., Smith, G.M., Bush, R.P., 2011. Design and Installation of a Disposal Cell Cover Field Test, WM2011 Conference, Phoenix, AZ.

Bjornstad, B.N., 2014. Ice-Rafted Erratics and Bergmounds from Pleistocene Outburst Floods, Rattlesnake Mountain, Washington, USA. Quaternary Science Journal 63, 44-59.

Bowerman, G., Redente, E.F., 1998. Biointrusion of Protective Barriers as Hazardous Waste Sites. Journal of Environmental Quality 27, 625-632.

Cadwell, L.L., Eberhardt, L.E., Simmons, M.A., 1989. Animal Intrusion Studies for Protective Barriers: Status Report for FY 1988, PNL-6869, Pacific Northwest Laboratory, Richland, WA.

Chamness, M.A., 1993. An Investigation of Bergmounds as Analogs to Erosion Control Factors on Protective Barriers, PNL-8841, Pacific Northwest Laboratory, Richland, Washington. Available at http://www.iaea.org/inis/collection/NCLCollectionStore/_Public/25/059/25059205.pdf

Christensen, J.H., Hewitson, B., Busuioc, A., Chen, A., Gao, X., Held, I., Jones, R., Kolli, R.K., Kwon, W.-T., Laprise, R., Magaña Rueda, V., L. Mearns, L., Menéndez, C.G., Räisänen, J., 
Rinke, A., Sarr, A., Whetton, P., 2007. Regional Climate Projections, in: Solomon, S., Qin, D., Manning, M., Chen, Z., Marquis, M., Averyt, K.B., Tignor, M., Miller, H.L. (Eds.), Climate Change 2007: The Physical Science Basis. Contribution of Working Group I to the Fourth Assessment Report of the Intergovernmental Panel on Climate Change Cambridge University Press, Cambridge, United Kingdom and New York, NY, USA, pp. 848-940.

DOE-EM, 2000. Innovatie Technology Summary Report - Alternative Landfill Cover, DOE/EM0558, U.S. Department of Energy Office of Environmental Management.

DOE-GJ, 1999. Composite Cover System for the Monticello Millsite Repository. US Department of Energy Grand Junction Office, Grand Junction Colorado.

DOE-LM, 2011a. Bluewater Site Fact Sheet, Department of Energy Office of Legacy Management, Grand Junction, Colorado. Available at http://www.lm.doe.gov/bluewater/Sites.aspx

DOE-LM, 2011b. Montecello Fact Sheet, in: Management, U.D.o.E.L. (Ed.), Grand Junction, Colorado.

DOE-RL, 1994. Constructability Report for the 200-BP-1 Prototype Surface Barrier, DOE/RL94-76, U.S. Department of Energy Richland Operations Office, Richland, Washington.

DOE-RL, 1999. 200-BP-1 Prototype Barrier Treatability Test Report, DOE/RL-99-11 Rev. 0, U.S. Department of Energy Richland Operations Office, Richland, Washington.

DOE-RL, 2016. Prototype Hanford Barrier 1994 to 2015, DOE/RL-2016-37, Rev. 0, U.S. Department of Energy Richland Operations Office, Richland, Washington. Available at http://www.hanford.gov/c.cfm/sgrp/DOE-RL-2016-37/DOE-RL-2016-37_R0.pdf (Accessed on June 14, 2016). 
DOE, 1996. Uranium Mill Tailings Remedial Action Project 1995 Environmental Report, DOE/AL/62350-218 Rev. 0, U.S. Department of Energy Albuquerque, New Mexico.

EPA, 1989. Technical Guidance Document: Final Covers on Hazardous Waste Landfills and Surface Impoundments, EPA-530-SW-89-047, U.S. Environmental Protection Agency, Washington, D.C.

EPA, 1991. Design and Construction of Rcra/Cercla Final Covers EPA/625/4-91/025, U.S. Environmental Protection Agency Office of Research and Development, Washington, DC.

EPA, 1992. Final Rule Corrections: Solid Waste Facility Disposal Criteria. Federal Register 57, 28626-28629.

EPA, 1996. Code of Federal Regulations Title 40: Protection of the Environment (1996ff.), U.S. Environmental Protection Agency, Washington, D.C.

Fayer, M.J., Gee, G.W., 2006. Multiple-Year Water Balance of Soil Covers in a Semiarid Setting. Journal of Environmental Quality 35, 366-377.

Fecht, K.R., Tallman, A.M., 1978. Bergmounds Along the Western Margin of the Channeled Scablands, South-Central Washington RHO-BWI-SA-11, Rockwell International, Richland, Washington. Available at http://www.osti.gov/scitech/servlets/purl/6431635

Freeman, H.D., Romine, R.A., Zacher, A.H., 1994. Hanford Permanent Isolation Barrier Program: Asphalt Technology Data and Status Report- FY 1994, PNL-10194, Pacific Northwest Laboratory, Richland, Washington.

Gano, K.A., States, J.B., 1982. Habitat Requirements and Burrowing Depths of Rodents in Relation to Shallow Waste Burial Sites, PNL-4140, Pacific Northwest Laboratory, Richland, Washington. 
Gee, G.W., 1987. Recharge at the Hanford Site: Status Report, PNL-6403, Pacific Northwest Laboratory, Richland, Washington.

Gee, G.W., Rockhold, M.L., Downs, J.L., 1989. Status of FY 1988 Soil-Water Balance Studies on the Hanford Site, PNL-6750, Pacific Northwest Laboratory, Richland, Washington.

Gee, G.W., Ward, A.L., Fayer, M.J., 1997. Surface Barrier Research at the Hanford Site. Land Contamination \& Reclamation 5, 233-238.

Gee, G.W., Ward, A.L., Gilmore, B.G., Ligotke, M.W., Link, S.O., 1995. Hanford PrototypeBarrier Status Report: FY 1995, PNL-10872, Pacific Northwest National Laboratory, Richland, Washington. Available at http://www.osti.gov/energycitations/servlets/purl/177965-nd9isN/webviewable/

Gee, G.W., Ward, A.L., Gilmore, B.G., Link, S.O., Dennis, G.W., O`Neil, T.K., 1996. Hanford Prototype-Barrier Status Report FY 1996, PNNL-11367, Pacific Northwest National Laboratory, Richland, Washington. Available at http://www.osti.gov/energycitations/servlets/purl/444009-twIbfZ/webviewable/

Gilmore, B.G., Walters, W.H., 1993. Water Erosion Field Tests for Hanford Protective Barriers: FY 1992 Status Report, PNL-8949 UC-603, Pacific Northwest Laboratory, Richland, Washington.

Hajek, B.F., 1966. Soil Survey Hanford Project in Benton County Washisngton, BNWL-243, Pacific Northwest Laboratory, Richland, Washington. Available at http://www.fsl.orst.edu/rna/Documents/publications/Soil\%20survey\%20Hanford\%20project \%20in\%20Benton\%20county\%20Washington.pdf

Hamon, W.R., 1963. Computation of Direct Runoff Amounts from Storm Rainfall. Internatinal Association Hydrological Sciences Publications 63, 52-62. 
Hauser, V.L., 2009. Evapotranspiration Covers for Landfills and Waste Sites. CRC Press, Boca Raton.

Henken-Mellies, W.U., Schweizer, A., 2011. Long-Term Performance of Landfill Covers Results of Lysimeter Test Fields in Bavaria (Germany). Waste Management \& Research 29, 59-68.

Hillel, D., 1980. Fundamentals of Soil Physics. Academic Press, New York.

Hoitink, D.J., Burk, K.W., Ramsdell (Jr.), J.V., Shaw, W.J., 2005. Hanford Site Climatological Summary 2004 with Historical Data, PNNL-15160, Pacific Northwest National Laboratory, Richland, Washington.

IAEA, 1989. Natural Analogues in Performance Assessments for the Disposal of Radioactive Wastes, Technical Reports Series No. 304, International Atomic Energy Agency, Vienna, Austria.

IAEA, 2004. The Long Term Stabilization of Uranium Mill Tailings, IAEA-TECDOC-1403, International Atomic Energy Agency, Vienna, Austria.

KEH, 1993. Prototype Surface Barrier at 200-BP-1 Operable Unit, W-263-C2 Rev. 0, Kaiser Engineers Hanford Company, Richland, Washington.

Landeen, D.S., 1990. Animal Intrusion Status Report for Fiscal Year 1989, WHC-EP-0299, Westinghouse Hanford Company, Richland, Washington.

Landeen, D.S., 1991. Animal Intrusion Status Report for Fiscal Year 1990, WHC-EP-0398, Westinghouse Hanford Company, Richland, Washington.

Landeen, D.S., 1994. The Influence of Small Mammal Burrowing Activity on Water Storage at the Hanford Site, WHC-EP-0730, Westinghouse Hanford Company, Richland, Washington. 
Ligotke, M.W., 1993. Soil Erosion Rates Caused by Wind and Saltating Sand Stresses in a Wind

Tunnel, PNL-8478, Pacific Northwest Laboratory, Richland, Washington. Available at http://www.osti.gov/energycitations/servlets/purl/6377761/

Ligotke, M.W., Klopfer, D.C., 1990. Soil Erosion Rates from Mixed Soil and Gravel Surfaces in a Wind Tunnel, PNL-7435, Pacific Northwest Laboratory, Richland, Washington.

Link, S.O., Waugh, W.J., Downs, J.L., Thiede, M.E., Chatters, J.C., Gee, G.W., 1994. Effects of Coppice Dune Topography and Vegetation on Soil Water Dynamics in a Cold-Desert Ecosystem. Journal of Arid Environments 27, 265-278.

Myers, D.R., Duranceau, D.A., 1994. Prototype Hanford Surface Barrier: Design Basis Document, BHI-00007 Rev.0, Bechtel Hanford, Inc., Richland, Washington.

Nyhan, J.W., 2005. A Seven-Year Water Balance Study of an Evapotranspiration Landfill Cover Varying in Slope for Semiarid Regions. Vadose Zone Journal 4, 466-480.

Petersen, K.L., 1994. The Long-Term Climate Change Task of the Hanford Permanent Isolation Barrier Development Program, in: Gee, G.W., Wing, N.R. (Eds.), Thirty-Third Hanford Symposium on Health and the Environment, November 7-11,1994. Battelle Press, Pasco, Washington, pp. 633-648.

Phillips, S.J., Ruben, M.S., Kirkham, R.R., 1988. Engineered Surface Barriers for Waste Disposal Sites: Lysimeter Facility Design and Construction, DOE Model Conference Proceedings, CONF-881054, pp. 1229-1238.

Rickard, W.H., Vaughan, B.E., 1988. Plant Community Characteristics and Responses, in: Rickard, W.H., Vaughan, B.E., Rogers, L.E. (Eds.), Shrub-Steppe: Balance and Change in a Semi-Arid Terrestrial Ecosystem, Developments in Agricultural and Managed-Forest Ecology. Elsevier, Amsterdam, pp. 109-179. 
Rockhold, R.L., Fayer, M.J., Gee, G.W., 1988. Characterization of Unsaturated Hydraulic Conductivity at the Hanford Site, PNL-6488, Pacific Northwest Laboratory, Richland, WA. Scanlon, B.R., Reedy, R.C., Keese, K.E., Dwyer, S.F., 2005. Evaluation of Evapotranspirative Covers for Waste Containment in Arid and Semiarid Regions in the Southwestern USA. Vadose Zone Journal 4, 55-71.

Schaetzl, R., Anderson, S., 2005. Soils Genesis and Geomorphology. Cambridge University Press, New York.

Schor, H.J., Gray, D.H., 2007. Landforming: An Environmental Approach to Hillside Development, Mine Reclamation and Watershed Restoration. John Wiley \& Sons, Inc., Hoboken, New Jersey.

Stone, W.A., Thorp, J.M., Gifford, O.P., Hoitink, D.J., 1983. Climatological Summary for the Hanford Area, PNL-4622, Pacific Northwest Laboratory, Richland, Washington.

Thornthwaite, C.W., 1931. The Climates of North America According to a New Classification. Geographical Review 21, 633-635.

Thornthwaite, C.W., Mather, J.R., 1955. The Water Balance. Publications in Climatology, Drexel Institute of Climatology, Centerton, NJ 8, 1-104.

Tirmenstein, D., 1999. Artemisia Tridentata Spp. Tridentata, in: U.S. Department of Agriculture Forest Service (Ed.), Fire Effects Information System. Rocky Mountain Research Station, Fire Sciences Laboratory (http://www.fs.fed.us/database/feis).

Wallace, R.W., 1977. A Comparision of Evapotranspiration Estimates Using Erda Hanford Climatological Data, PNL-2698, Battelle Pacific Northwest Laboratories, Richland, Washington. 
Ward, A.L., Gee, G.W., 1997. Performance Evaluation of a Field-Scale Surface Barrier. Journal of Environmental Quality 26, 694-705.

Waugh, W.J., 2011. DOE Experience with Cover Degradation Processes, Design Improvements, and Cover Renovation for Uranium Mill Tailings Disposal Cells, Workshop on Engineered Barrier Performance Related to Low-Level Radioactive Waste, Decommissioning, and Uranium Mill Tailings Facilities, U.S. Nuclear Regulatory Commission Headquarters, Rockville, Maryland.

Waugh, W.J., Chatters, J.C., Last, G.V., Bjornstad, B.N., Link, S.O., Hunter, C.R., 1994. Barrier Analogs: Long-Term Performance Issues, Preliminary Studies, and Recommendations, PNL9004, Pacific Northwest Laboratory, Richland, WA.

Waugh, W.J., Kastens, M.K., Sheader, L.R.L., Benson, C.H., Albright, W.H., Mushovic, P.S., 2008. Monitoring the Performance of an Alternative Landfill Cover at the Monticello, Utah, Uranium Mill Tailings Disposal Site, WM2008 Conference, February 24-28, 2008 Phoenix, Arizona.

Waugh, W.J., Smith, G., Danforth, B., Gee, G.W., Kothari, V., Pauling, T., 2007. Performance Evaluation of the Engineered Cover at the Lakeview, Oregon, Uranium Mill Tailings Site, Proceedings of Waste Management 2007, Tucson, Arizona.

Wing, N.R., Gee, G.W., 1994. Quest for the Perfect Cap. Civil Engineering 64, 38-41.

Zhang, Z.F., 2015. Field Soil Water Retention of the Prototype Hanford Barrier and Its Variability with Space and Time. Vadose Zone Journal 14, 1-10.

Zhang, Z.F., 2016a. Evaluating the Long-Term Hydrology of an Evapotranspirationcapillary Barrier with a 1000 Year Design Life. Water Resources Research 52. 
Zhang, Z.F., 2016b. Prototype Hanford Barrier Monitoring. In DOE-RL, Prototype Hanford Barrier 1994 to 2015, Appendix C, DOE/RL-2016-37, Rev. 0, U.S. Department of Energy Richland Operations Office, Richland, Washington.

Zhang, Z.F., 2016c. Side Slopes Impact to the Hydrology of a Long-Term Surface Barrier System. Water (Submitted in May 2016). 
Table 1. Barrier design/performance objectives and monitoring methods

\begin{tabular}{|c|c|}
\hline Objectives & Monitoring Items and Methods \\
\hline $\begin{array}{l}\text { \#1 Meet or exceed } \\
\text { RCRA criteria }\end{array}$ & No regular monitoring \\
\hline $\begin{array}{l}\text { \#2 Function in a } \\
\text { semiarid to subhumid } \\
\text { climate }\end{array}$ & $\begin{array}{l}\text { - The weather conditions were measured in a nearby } \\
\text { meteorological station. }\end{array}$ \\
\hline $\begin{array}{l}\text { \#3 Limit drainage } \\
\text { through the silt to } \\
\text { less than } 0.5 \mathrm{~mm} \mathrm{yr}^{-1}\end{array}$ & $\begin{array}{l}\text { Drainage rates from } 12 \text { zones were captured by } 12 \\
\text { lysimeter-type systems and measured hourly. with } 12 \\
\text { drainage collection vaults, respectively } \\
\text { - Water content in the silt loam was measured at } 12 \\
\text { locations with a neutron probe from weekly to } \\
\text { monthly. } \\
\text { - The vegetation condition and animal activities were } \\
\text { surveyed annually. }\end{array}$ \\
\hline \#4 Limit runoff & - Runoff was monitored by a $15 \times 6 \mathrm{~m}$ flume hourly. \\
\hline \#5 Minimize erosion & $\begin{array}{l}\text { - Water-induced soil erosion was monitored by a } 15 \times 6 \\
\text { m flume hourly. } \\
\text { - Wind stress was monitored by measuring wind speed } \\
\text { at different heights at three locations from } 1994 \text { to } \\
1997 \text {. } \\
\text { - The vegetation condition was surveyed annually. }\end{array}$ \\
\hline $\begin{array}{l}\text { \#6 Minimize biotic } \\
\text { intrusion }\end{array}$ & - Animal activities were surveyed annually. \\
\hline $\begin{array}{l}\text { \#7 Have a design life } \\
\text { of } 1000 \text { years }\end{array}$ & $\begin{array}{l}\text { - Subsidence was monitored with two settlement } \\
\text { markers. } \\
\text { - Soil erosion was monitored by measuring the barrier } \\
\text { elevations at } 338 \text { locations annually. } \\
\text { - The riprap slope stability was surveyed annually with } \\
15 \text { creep gauges. } \\
\text { - Aerial photos were taken annually for the barrier and } \\
\text { surrounding area. } \\
\text { Events that may impact barrier performance were } \\
\text { examined with ad-hoc investigation. }\end{array}$ \\
\hline $\begin{array}{l}\text { \#8 Be maintenance } \\
\text { free }\end{array}$ & No regular monitoring \\
\hline
\end{tabular}


Table 2. The layer structure of the surface barrier and their functions.

\begin{tabular}{|c|c|c|c|c|}
\hline $\begin{array}{l}\text { Layer } \\
\text { No. }\end{array}$ & Materials & $\begin{array}{l}\text { Layer } \\
\text { Thickness } \\
\text { (m) }\end{array}$ & Layer Function & Notes \\
\hline 0 & Vegetation & NA & $\begin{array}{l}\text { Release stored water into the } \\
\text { atmosphere by ET; protect barrier } \\
\text { surface from wind- and water- } \\
\text { induced soil erosion }\end{array}$ & $\begin{array}{l}\text { Revegetated native plant } \\
\text { species }\end{array}$ \\
\hline 1 & $\begin{array}{l}\text { Upper Silt } \\
\text { Loam w/ Pea } \\
\text { Gravel } \\
\text { Admix }\end{array}$ & 1.0 & $\begin{array}{l}\text { Provide medium for plant growth } \\
\text { and water storage; minimize soil } \\
\text { erosion by adding the } 15 \% \text { pea } \\
\text { gravel }\end{array}$ & $\begin{array}{l}2 \% \text { slope from the crown } \\
\text { (north-south center line) }\end{array}$ \\
\hline 2 & $\begin{array}{l}\text { Lower Silt } \\
\text { Loam }\end{array}$ & 1.0 & $\begin{array}{l}\text { Provide medium for plant growth } \\
\text { and water storage }\end{array}$ & $2 \%$ slope from the crown \\
\hline 3 & Geotextile & NA & $\begin{array}{l}\text { Prevent the fine silt loam from } \\
\text { entering the underlying coarser } \\
\text { sand layer during construction }\end{array}$ & \\
\hline 4 & Sand Filter & 0.15 & $\begin{array}{l}\text { Prevent silt loam from falling into } \\
\text { the gravel filter }\end{array}$ & \\
\hline 5 & Gravel Filter & 0.3 & $\begin{array}{l}\text { Prevent gravel from falling into } \\
\text { the basalt riprap }\end{array}$ & \\
\hline 6 & $\begin{array}{l}\text { Basalt } \\
\text { Riprap }\end{array}$ & 1.5 & $\begin{array}{l}\text { Prevent digging by humans and } \\
\text { burrowing by animals, and } \\
\text { penetration by roots }\end{array}$ & \\
\hline 7 & $\begin{array}{l}\text { Drainage } \\
\text { Gravel }\end{array}$ & 0.3 & $\begin{array}{l}\text { Protect the underlying layer; } \\
\text { medium for lateral water } \\
\text { movement }\end{array}$ & \\
\hline 8 & $\begin{array}{l}\text { Asphalt } \\
\text { Concrete }\end{array}$ & 0.15 & $\begin{array}{l}\text { Divert potential infiltration water } \\
\text { away from the waste zone; prevent } \\
\text { noxious gases from moving } \\
\text { upwards out of the waste zone }\end{array}$ & $\begin{array}{l}\text { AC with 5-mm-thick FAA } \\
\text { coating; the layer is curbed } \\
\text { and drainage water is guided } \\
\text { out to designated area }\end{array}$ \\
\hline 9 & Top Course & 0.1 & $\begin{array}{l}\text { Provide stable base for the asphalt } \\
\text { concrete }\end{array}$ & \\
\hline 10 & $\begin{array}{l}\text { Compacted } \\
\text { Sandy Soil } \\
\text { Fill }\end{array}$ & Variable & $\begin{array}{l}\text { Provide foundation of the top } \\
\text { layers }\end{array}$ & \\
\hline
\end{tabular}




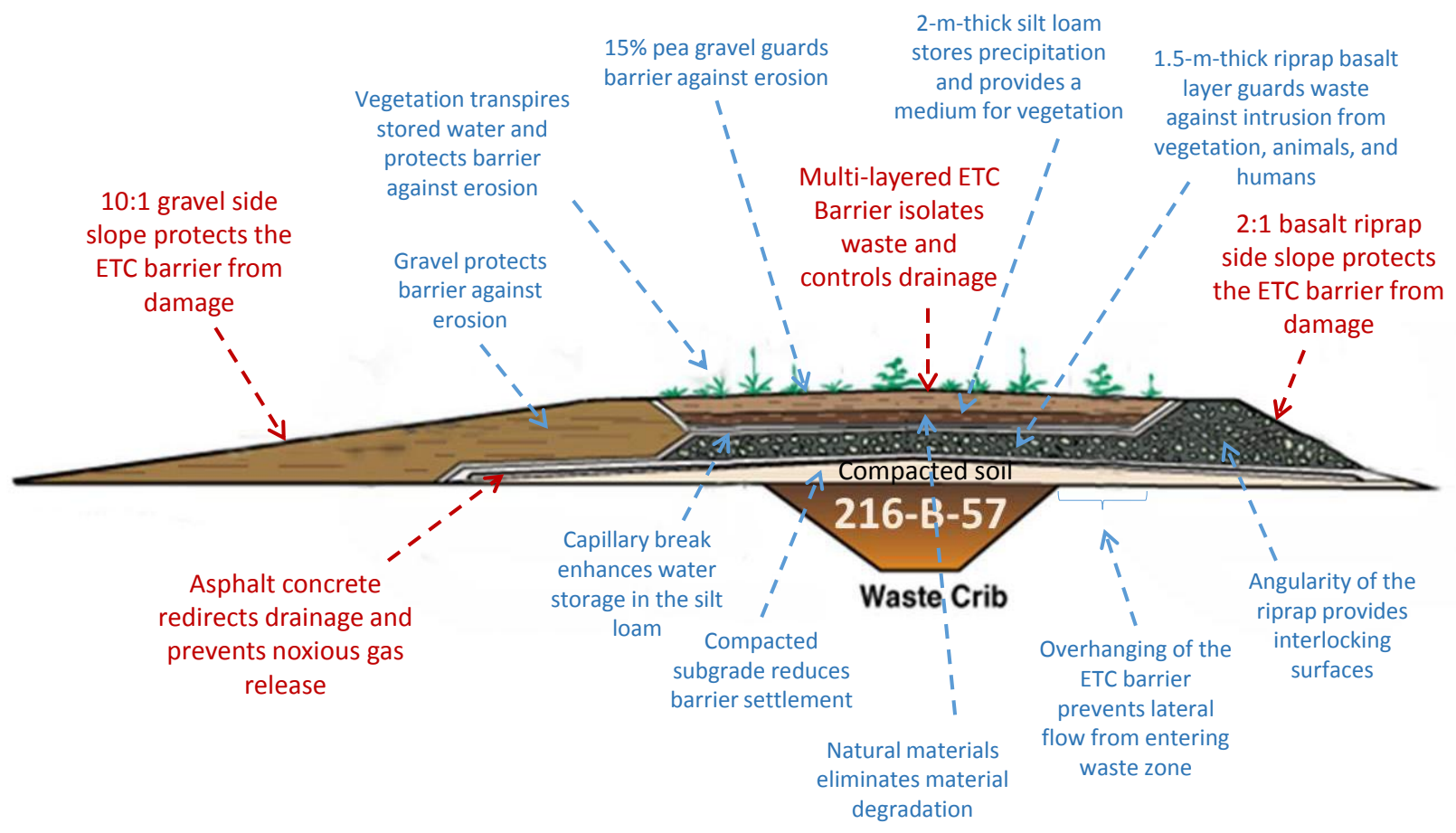

Figure 1. The west-east cross-section of the Prototype Hanford Barrier. 


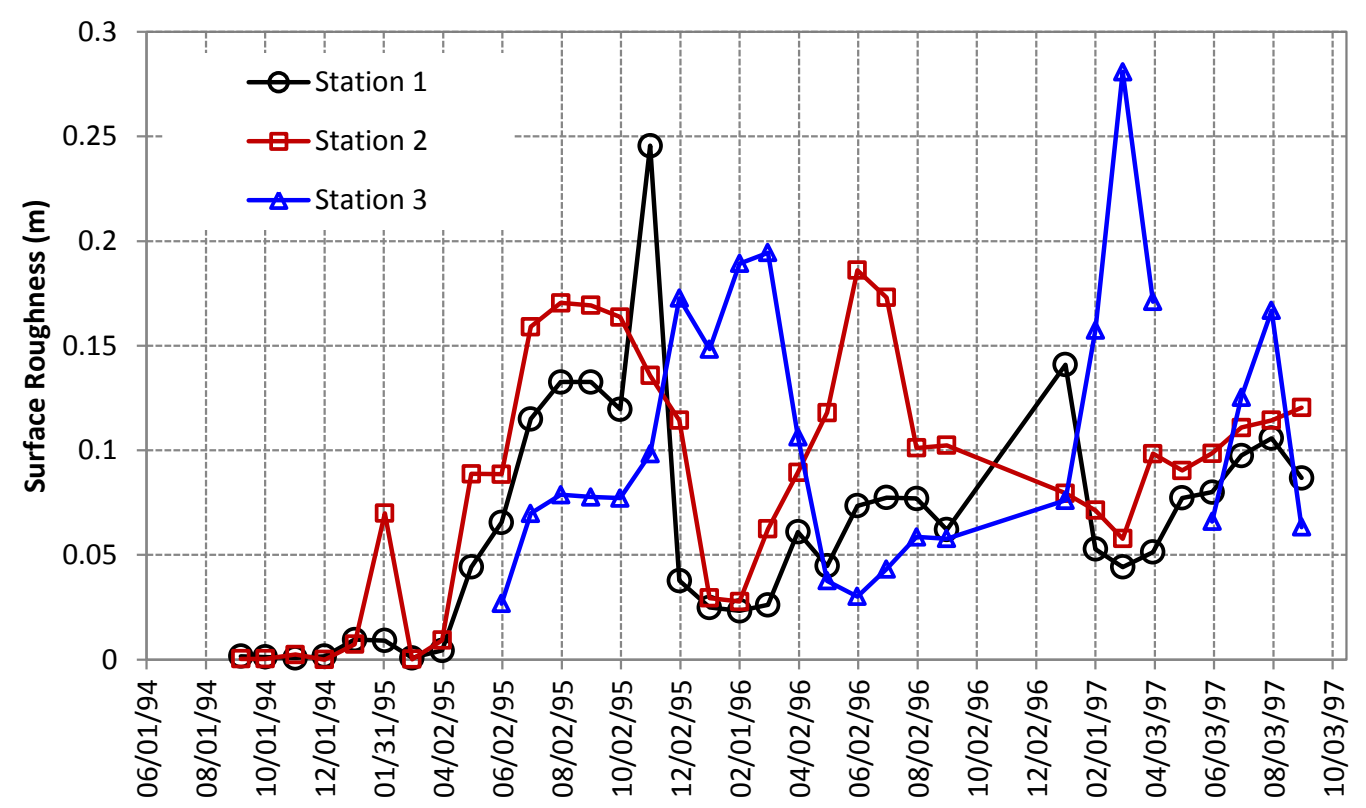

Figure 2. Barrier surface roughness based on monthly average wind profiles. 

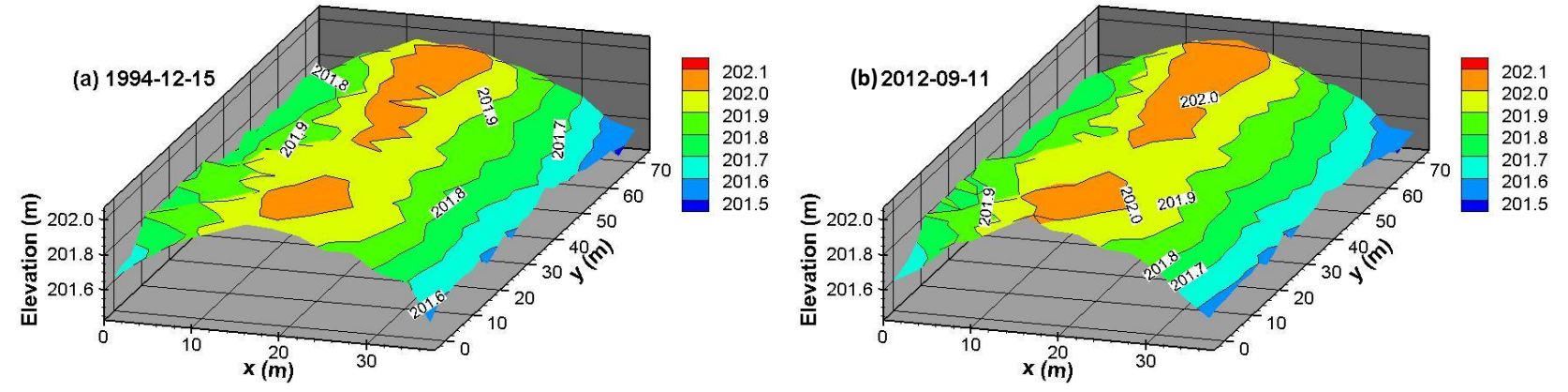

Figure 3. Surface elevation contours of the Prototype Hanford Barrier in (a) 1994 and (b) 2012. 


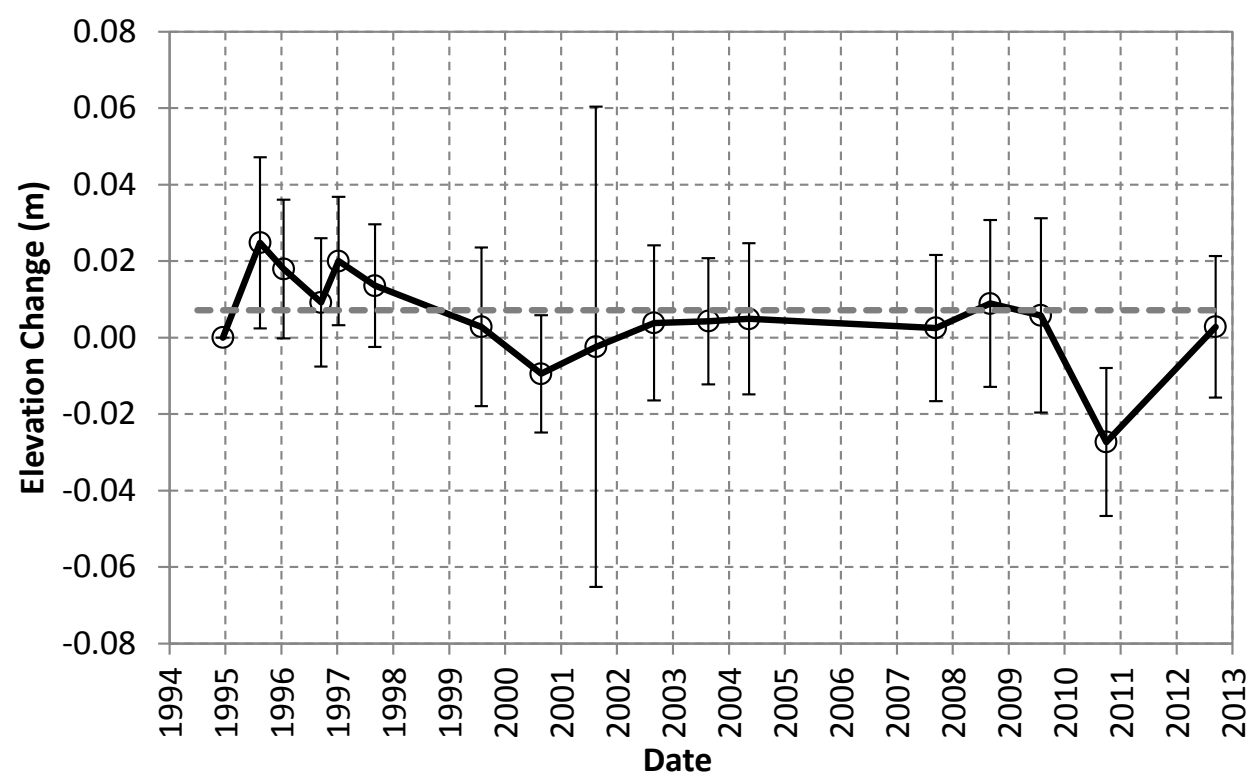

Figure 4. Average surface elevation change over 338 observations of the Prototype Hanford Barrier. Vertical lines indicate one standard deviation. 


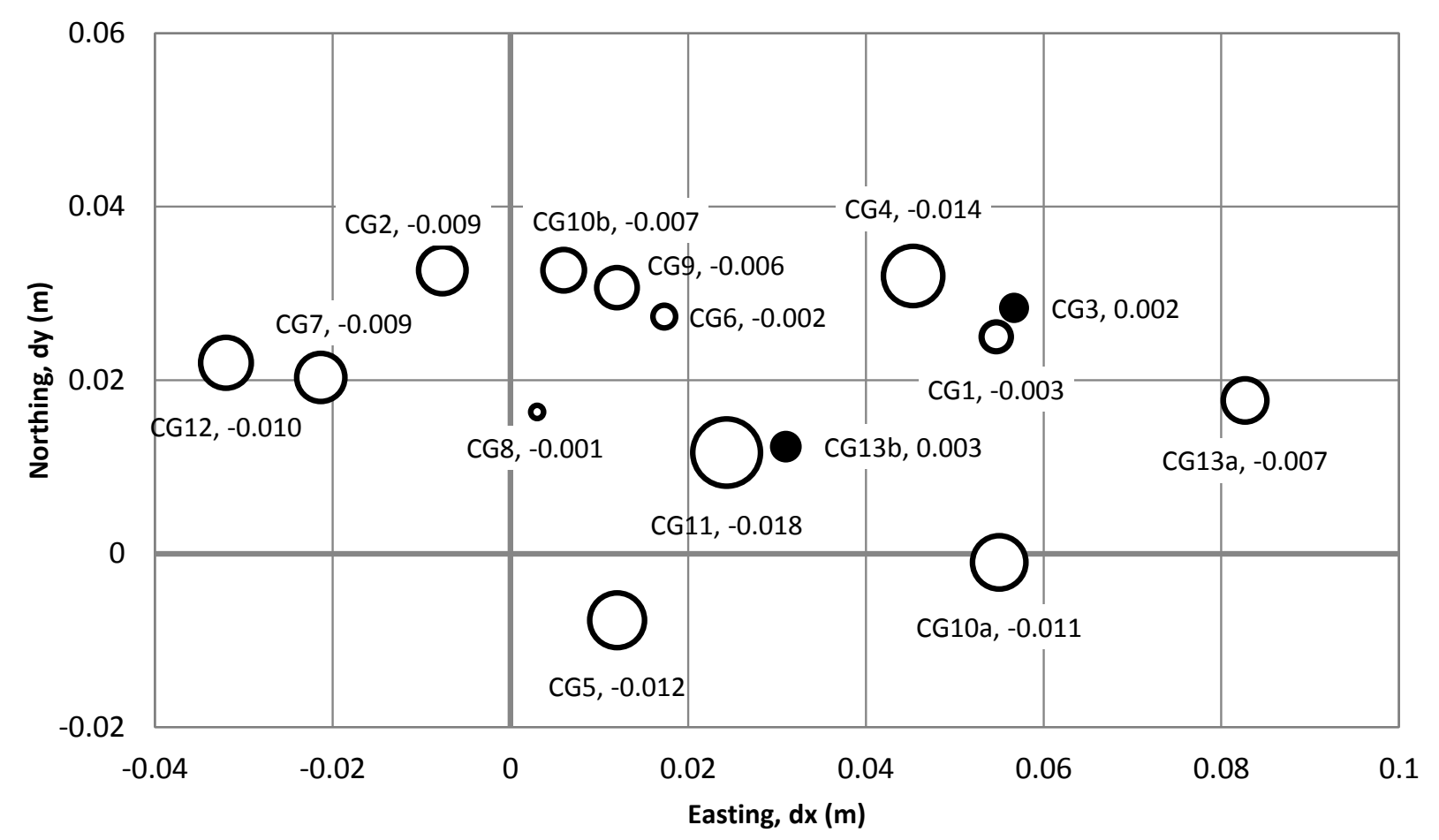

Figure 5. Positions of creep gauges in 2012 (2011 for CG12 and 2010 for CG10a) relative to their corresponding initial positions. A positive dx value indicates lateral movement of the side slope outward. A filled bubble indicates an increase in CG elevation, while an empty bubble indicates a decrease. The area of the bubble indicates the change in elevation as shown by the number nearby. 

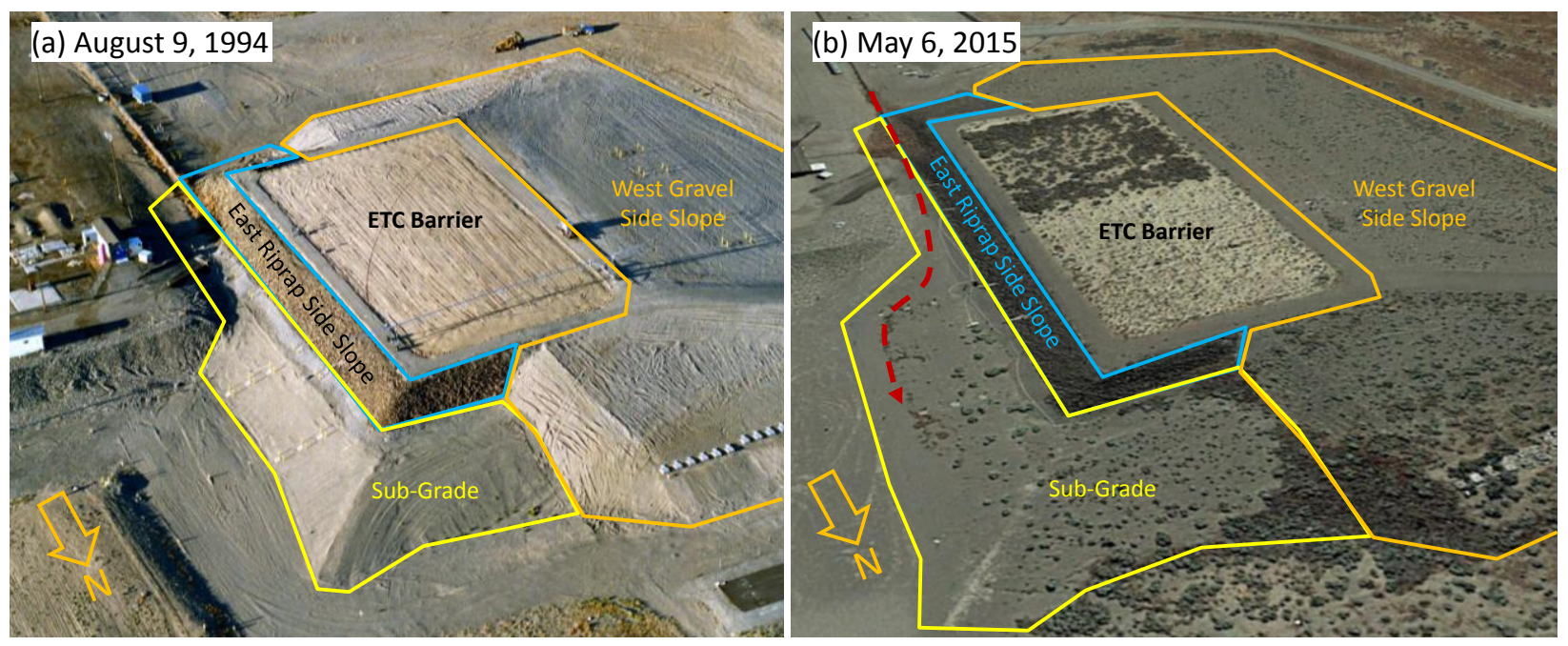

Figure 6. Comparison of the Prototype Hanford Barrier (a) in 1994 after the completion of construction and (b) in 2015. The solid lines show the approximate boundaries of some barrier components. The dashed line indicates the approximate path and direction of the runoff water in May 2004 after severe thunderstorms. The image in (b) is from Google Earth. 